\title{
AC 2010-437: EXPLORING THE VALUE OF DESIGN AND BUILD EXPERIENCES FOR UNDERGRADUATE ENGINEERING STUDENTS
}

Robert Prins, James Madison University

Eric Pappas, James Madison University 


\section{Exploring the Value of Design and Build Experiences for Undergraduate Engineering Students}

\section{Introduction}

In August 2008, James Madison University (JMU), traditionally known as a liberal arts university, enrolled its first engineering students into a unique engineering product and process design and build program focused on sustainable design. A noteworthy component of this integrated design and build program is the six-semester 10-credit design studio sequence that stretches from the sophomore year to graduation, and includes significant project work. The design and build component of the program is introduced in our Freshman Introductory course (Engineering 112). We present a divergence from the generally accepted approach to sustainability (normally referred to as "sustainable engineering" or "environmental sustainability") and include instruction in creating sustainable societies.

Design instruction in our undergraduate studio design sequence spans freshman through senior years and focuses on sustainability in four contexts: environmental, socio-cultural, economic, and technical. Students learn to design (and re-design) for sustainability in all contexts and are required to build (or model) their designs. Throughout the program, students are required to design or re-design products and processes that are subject to sustainability criteria we developed for student projects. In addition to design instruction and practice, students receive group and individual instruction in the use of hand and machine tools. (e.g. drills, band saw, lathe).

Our approach to teaching design includes instruction in critical thinking practices - the intentional and directed cognitive processes and habits that foster effective thinking. This approach includes projects that require students to physically construct their designs as part of the design iteration process. Our assertion is that critical thinking in combination with hands-on project experience inspires better design.

This paper describes the second of three stages of initial research into instruction in tool use, cognition, and design: an almost entirely undocumented area of engineering research. "Tool use" in this context refers to hand and machine tools as may be found in a typical shop. Our results are general but encouraging, and research continues each semester. Our targeted third stage will be under way in spring 2010 and will be presented in an upcoming paper.

This effort is funded by National Science Foundation IEECI Grant \#10-00017 and National Science Foundation CCLI Grant \# 0837465.

\section{Literature Review}

There is very little in the formal engineering literature addressing cognitive process development related to hand or machine tool use. Much of the research on tool use, design, and cognition is found in the psychology and education literature.

Cognition and tool use research in engineering, outside of using computers as cognitive tools, ${ }^{1,2}$ is a largely unexplored area; however, some authors provide research into the nature of tool-use 
related creativity, design skill and tool-use improvement, and the assessment of students' improvement in problem solving skills through cognitive tool use.

As an interdisciplinary and alternative approach to learning styles, Keller and Keller note that visual imagery and physical virtuosity, rather than verbal logic can serve as legitimate areas of cognitive inquiry, in this case, the study of blacksmithing. ${ }^{3}$ Malicky, et al. focus on inductive learning in their University of San Diego machine shop class in mechanical engineering. ${ }^{4}$ Through the use of hand tools like the miter saw, drill press, sander, and band saw in active learning projects, the authors surmised that students constructed more theoretical knowledge structures than with instruction that did not focus on inductive problems.

In their description of the phases through which industrial engineering endured, Bailey and Barley note several facts related to tool use and cognition. ${ }^{5}$ Of particular relevance to this paper is their suggestion that in the current industrial engineering evolutionary scheme, the study of ergonomics is giving way to interests related to risk analysis, decision making, and cognitive psychology in shop practices and factory methods.

Much of the research on tool use and cognition emerges from the concepts "situated learning" or "situated cognition," which Brown defines as "that knowledge is situated, being in part a product of the activity, context, and culture in which it is developed and used"6 (p.32). The authors suggest that the use of the tool and the attendant setting are inseparable as far as cognitive processes are concerned, whether the tools be chisels and saws, or computers. The authors further suggest that "learning in a domain [a field of study with common characteristics-Ed.] enables students to acquire, develop, and use cognitive tools in authentic domain activity" (p.39); that is, using tools increases cognitive activity and ability. Salomon writes of his disagreement with Brown (above), and argues that the interaction between a human being and an intelligent tool (computer) results in a favorable "cognitive residue" (p.5) that does not result from the interaction between a tool user and a non-intelligent tool ("situated"). 7 The "cognitive residue" that results in these situations is that the use of intelligent tools may result in thinking skills being transferred to other dissimilar, or at least similar, situations (but the author notes that too little research has been done in this area).

Vygotsky's notion that understanding is social in origin, ${ }^{8}$ argues Cole, is in direct contrast to Piaget, ${ }^{9}$ who claims that children develop cognitive abilities by doing. ${ }^{9}$ Dewey suggests that both social and individual experiences produce an interweaving of biology and human experience ("doing"). ${ }^{10}$ Cole and Wertsch suggest that such learning processes are "mediated," that is, that "direct action" is an indirect action, one that relies upon previous experience and incorporates it into the current action. ${ }^{11}$ This argument of "distributed cognition" suits well the research and contention of the current paper-that increasing cognitive ability through tool use and design projects may well be one based on students' prior experience with tools as well as the cognitive condition that results from actually using the tool. (Distributed cognition suggests that human knowledge and cognition are not confined to the individual, rather, they are distributed by placing knowledge of, memory, or facts, in this case, on tools in our environment.)

Pea suggests that the use of tools interfaces to complex tasks, socially constructed as well as brought about by individual differences. ${ }^{12}$ He notes: "By shaping nature and how our 
interactions with it are mediated, we change ourselves."13 Maravita and Iriki suggest that tool use "creates changes in specific neural networks that hold an updated map of body shape and posture...a Body Schema"14 (p.1). This effect would lend support to what we already know as "experience using tools" in that cognitive changes accompany repeated tool use. The author continues: "To act efficiently in space, our brain must not only localize any objects of interest in extrapersonal space but also hold a constantly updated status of the body shape and posture"15 (p.1). There is little doubt this factor would increase cognitive tool use through familiarity of motion and tool effect.

\section{Inquiry and Discussion}

In the process of developing the hands-on portion of our curriculum, we have engaged in an ongoing discussion related to the value of such an approach. This discussion has led us to consider the immediate value of hands-on experiences as well as its potential broader impacts. We include the following (unfinished and somewhat tentative) discussion as a way to share our thoughts and questions in the hope that we will initiate conversation with other interested parties. Two questions we have discussed can be stated as: "Why do we do it?" and "Why do we need to do it?"

\section{Why do we do it?}

Our program is limited to undergraduate students who are seeking a Bachelor of Science in Engineering degree; we do not offer degrees in specific engineering disciplines. That said, we expect that over the course of their education, many of our students will begin to identify with a specific sub-discipline. At first glance it may seem that an assignment requiring students to build a part using a lathe could have considerable value to a student with interests in mechanical or manufacturing engineering, but may be of limited value to a student with interests in (say) environmental engineering. Broadly speaking, we could say that the domain knowledge associated with such a project is more closely related to some engineering fields than to others. While we agree with this, we suggest that there may be a broad (discipline spanning) value in understanding "how things work" (general procedural knowledge). In other words, the hands-on nature of the projects has value for a given student even if the associated domain knowledge is not closely associated with his or her disciplinary interests. We explore our rationale for this in the following paragraphs.

In order to describe phenomena that are not readily observed on a daily basis, teachers often use analogies. For instance, direct current circuits are often described through the analogy of water flow. Such an analogy makes a lot more sense if a student has rudimentary experience with hydraulics - or even observations of water in a ditch. We contend that the physical nature of "build activities" develops a person's instinctive or intuitive knowledge of the physical world to the point that their understanding of analogies is enriched.

We anticipate that upon graduation our students are likely to either go directly to work as engineers or enroll in a discipline-specific graduate program. In either case, it is easy to imagine instances where having some hands-on experience will be of value. The "fresh" engineer or graduate student stands a good chance of being involved with some tangible item; perhaps as 
part of on-going development or maintenance of test apparatus, or the development of a specific product or fixture. An engineer or student who has some level of hands-on experience is more likely to be able to perform small or simple tasks themselves, and is more likely to establish meaningful communication with technicians whose expertise may be necessary to complete more complex tasks.

On a more esoteric level, certain scholars are calling for a reconsideration of the prevailing theories that link the human brain to action. In his book that explores the influence that the hands have on human development (The Hand), Frank Wilson suggests that the hand provides the brain with as much information as the brain provides the hand. ${ }^{16}$ In other words, don't think of the human body as a machine with the brain as the controller and the hand as the end effector at the end of some manipulator arm. The connection between hand and brain is more nuanced than that. Wilson states:

"The reason [brain] messages were going to the hands in the first place was so that the hands would reach for, grasp, touch, turn, weigh, join, separate, bounce, and so on, whatever it was that came into their possession. The hands were moved, among other reasons, to obtain information that could be obtained only by acting upon the object being held. The information returned to the brain was written in the tactile and kinesthetic language of manipulation, and was compared with information coming from the visual system, as part of a process through which the brain creates visuospatial images." 17

This suggests a strong correlation between the manipulation of objects by hand and physical understanding of objects and materials. Wilson further indicates that intelligence is best cultivated using methods which employ both mind and body.

Why do we need to do it?

Over the last 10-20 years, senior capstone projects that often include a hands-on component have become popular in engineering curricula. More recently, a significant number of engineering educators have begun to include hands-on work at the freshman level as well. As an example of this see the newly developed curriculum for all freshman engineering students (regardless of discipline) at Louisiana Technological University. ${ }^{18}$ If we anticipate this trend, we might predict four years of hands-on work as part of a typical engineering degree of the future. This would indeed be a significant change to other current trends in engineering education that tend to place a greater value on electronic and software based tools, but is it necessary? Is it more necessary now than perhaps 40 years ago? If the role of the engineer fits somewhere between the roles of "scientist" and "technician," one might assume that engineer training should prepare an engineer to interface with both groups. Is it possible that societal changes have made it less likely for an average engineer to be able to communicate meaningfully with an average technician than he or she might have 40 years ago? Perhaps. Is our general movement as a society away from farms and rural areas to urban areas in combination with an increase in affluence reducing or removing a young person's opportunity to tinker? If there is no machinery to fix (or observe being fixed), no ditches to dam, and if one calls the plumber to replace a leaky faucet or discards a toaster when it no longer functions as new, where would one learn "how stuff works"? 
Where does one develop a visceral sense of the physical world? We suggest that this may go beyond having a "gut feeling" that water should flow downhill; the world is composed of lots of little things (small objects, events, and processes) - and a change in any one of these produces seemingly unpredictable changes in the others that may or may not be apparently connected. An appropriate breadth of experience may allow students to see this for themselves and become aware of unintended consequences associated with large systems. There is much to learn from active hands-on experience that cannot be learned from passive information transfer; if students do not come to us with appropriate experiences then perhaps we need to assist them.

\section{Training for studio work}

Although our program includes a significant hands-on construction component, we do not assume our students arrive with the required skills. In order to prepare students for studio work, we provide initial training in the freshman engineering course (Engineering 112). As part of Engineering 112, students participate in an initial introductory session (studio boot camp) and four additional sessions for a total of $4 \frac{1}{2}$ hours of training. Studio boot camp includes safety information as well as training in the use of basic hand tools; power tool and machine tool instruction is covered in subsequent sessions. The training session takes place in the Engineering Design Studio, a purpose-built facility that includes $1200 \mathrm{ft}^{2}$ of instructional space and $600 \mathrm{ft}^{2}$ of construction space. The instructional space includes 15 large laboratory benches and can also be used for assembly tasks. The construction space contains workbenches, tools, and materials for construction. Additional details on the training and construction space can be found in our previous paper. ${ }^{19}$

\section{A) Boot Camp Description}

Studio boot camps are inhave three components: 1) safety and procedural rules, 2) tool usage instruction, and 3) tool usage exercises. Our safety rules are fairly standard and address proper attire as well as decorum. A list of our rules can be found in our previous paper. ${ }^{20}$ During the instruction portion of boot camp, we attempt to cover tool operations required for simple construction based on our best estimate of what tools will be most useful. To this end we include cutting with hand saws, drilling, and fastening. Demonstrations of sawing and drilling layout and operation are fairly pedantic and designed to promote an orderly approach to each process. Students work in pairs to repeat the demonstrated work; each student produces the required cuts and drilled holes. The fastening process is discussed but not demonstrated, students work in pairs to produce the required output of a butt joint using two pieces of nominal 2"x 4" pine.

\section{B) Additional Instruction Sessions}

Four additional instruction sessions are included in Engineering 112 as part of the laboratory experience. These sessions cover setup and the operation of drills, various saws, and a "Smithy" machine that can be configured as a lathe, mill, or drill press. Each session lasts approximately 30 minutes and includes some hands-on work by the students but at a less intense level than the boot camp. Sessions typically include one instructor and approximately 10 students. A project 
is assigned after students are familiarized with drills and saws; a second project is assigned after the lathe session. No project associated with the mill is assigned in Engineering 112.

\section{Drills and Taps}

Students are introduced to power drilling operations and tapping operations through a pre-lab reading assignment and a live demonstration. The pre-lab reading consists of nine pages of images and brief text describing the tools, nomenclature, and operations related to drilling and tapping. During a 30-minute laboratory session, students observe live demonstrations of drilling and tapping procedures followed by a group exercise in which students work as a team to generate a tapped hole.

$\underline{\text { Saws }}$

Students are introduced to powered saws and their operation through a pre-lab reading assignment and online quiz, as well as a live demonstration. The pre-lab reading consists of eight pages of images and brief text describing the tools, nomenclature, and operations related to saws. Students are required to take a short online quiz to encourage completion of the pre-lab reading assignment. During a 30-minute laboratory session, students observe live demonstrations of saw operations. During the saw demonstration, two to three students have the opportunity to participate in using a powered saw to cut a piece of wood or steel. Although time does not permit all students to operate each saw during the demonstration session, it is valuable for students to observe their peers struggle but succeed in the use of powered saws.

$\underline{\text { Lathe }}$

Students are introduced to lathe setup and operation through a pre-lab reading assignment and online quiz, as well as a live demonstration. The pre-lab reading consists of nine pages of images and brief text describing the tools and nomenclature related to lathes as well as lathe setup and operation. Where practical, the images used were of the actual tool that students use to complete their projects. Students are required to take a short online quiz to encourage completion of the pre-lab reading assignment. Students observe a live demonstration of lathe operations in a 30-minute laboratory session. During the demonstration, one or two students participate in determining an acceptable gear combination for autofeeding and adjust the lathe settings to that gear combination. This serves to demonstrate to the group that the gear selectors can be difficult to operate, but success is possible.

$\underline{\text { Mill }}$

Students are introduced to mill setup and operation through a pre-lab reading assignment and a live demonstration. The pre-lab reading consists of six pages of images and brief text describing the tools and nomenclature related to mills, as well as mill setup and operation. Where practical, the images used were of the actual tool that students use to complete their projects. During a 30minute laboratory session, students observe a live demonstration of mill operation. During the demonstration, one or two students participate in determining an acceptable gear combination for autofeeding, and adjust the settings to that gear combination. 


\section{Student Projects}

Students participate in three construction projects in Engineering 112 and one in the first course in the design series (Engineering 231). The projects in Engineering 112 are: 1) a block assembly "widget," 2) a lathe part, and 3) a semester design project in which the level of specification is reduced with each assignment. The widget assembly is completely specified, the lathe part requires the students to perform certain operations, but the final product is unspecified. The semester design project has broad requirements, but no specifications. In Engineering 231, students are tasked with the design and construction of a Go-NoGo gauge for the inspection of a hole. Each project is described below; additional details related to the widget and lathe projects are available in Design and Build: Teaching Cognitive Skills through Tool Use. ${ }^{21}$ In both the current study and the aforementioned one, "tools" refers to the use of hand and machine tools (drill press, lathe, tap, band saw, etc).

\section{A) Widget}

The widget assembly is assigned after students participate in the drill and saw demonstrations described above. The project requires students to construct two blocks of aluminum that must be fastened together using screws and threaded holes. The project requires students to perform three tapping operations that require different taps and tap drills, and students use the drill press to drill through holes as well as perform counterbore and countersink operations. Accurate layout methods are rewarded with an assembly that can be screwed together.

\section{B) Lathe Part}

The lathe assignment allows students to produce a part of their own choosing as long as the part demonstrates facing and turning operations. A score of $75 \%$ is proposed for a cylindrical part that has been faced and turned. In order to achieve a higher score, students need to add details such as tapers, grooves, or holes as well as a stated purpose or use.

\section{C) Go-NoGo Gauge}

In this assignment, students are individually tasked with the design and construction of a GoNoGo gauge to be used to test a specific hole for which the nominal size and tolerance are given. Students are given a brief introduction to Go-NoGo gauges to accompany the distribution of the assignment, and are informed that success in this assignment will require them to learn more on their own. A simple internet search (typing "go nogo" into Google, for example) will lead students to additional information.

Figure 1 shows the actual assignment given to the students. Our intention is that this assignment will cause students to think through at least some of the wide range of practical and common sense issues associated with their design, for instance:

- Interaction of users with design

- Interaction between tolerances on the gauge itself with the tolerance of the part that the gauge will be used to inspect 
- Differentiation between parts that fail and the disposition of these parts, for instance:

- Level one: differentiate based on failure mode

- Hole too small can be enlarged (rework)

- Hole too large cannot be un-enlarged (scrap)

- Level two: tolerance of gauge itself could lead to false failures

- Use more accurate measurement device to audit failed parts

- $\quad$ Communication with machinist who will construct the gauge (in this case themselves)

Part of your job includes providing engineering support to a production facility-

The production manager has requested that you provide a Go-NoGo gauge to

allow production workers to quickly determine if a hole in one of the parts is

within specification. The hole in question is dimensioned as $1.000 \pm 0.040$

(dimensions in inches) and goes through a plece of $\% \%^{\prime \prime}$ steel plate.

1. Design a Go-NoGo gauge that can be used to verify that the hole is within the limits imposed by the tolerance. In your design consider the following:

a. Ease of use

b. Error-proofine (could it be used in a way that would produce an incorrect result?)

c. Time required to use gauge and interpret results

Develop multiple designs and chose one as your primary design. This work will be reviewed so keep good records in your design journal.

Prepare a document that addresses items 2, 3, and 4

2. Provide descriptions of each of your designs; compare them and indicate why you selected one as your primary design. Describe how your primary design is intended to be used.

3. Discuss the critical dimensions in your primary design, any tolerances required, and why you chose those tolerances.

4. What should be the disposition of parts that do not pass? (What do you recommend gets done to the bad parts?)

5. Senerate an $A+C A D$ model of your orimary desian. include dimensions and tolerances. Turn in a printed copy.

6. Prototype your gauge in the Design Studio; we recommend aluminum as a prototype material. Turn in the following:

a. Prototyped part

b. Copy of (5) with hand written "as built" measurements for critical dimensions

Parts 1-5 are due in class in one week. Part 6 is due in class in three weeks.

Figure 1: Go-NoGo Gauge Assignment 
This project requires students to apply general skills previously learned or studied including CAD operation, dimensioning, lathe operation, and inspection tool operation.

\section{D) Semester Design Project}

The principal objective of this Engineering 112 project is to introduce students to an individualized design process. A secondary, but nonetheless important, objective is to introduce students to sustainability in four contexts (environmental, social, economic, and technical). Since students had no experience with the design process (but had been introduced to problem solving processes earlier in the semester), our approach was fairly strict: Each student had to follow the prescribed cognitive approach to developing a design, which included structured problem solving, visualization, drawing, and reflection to build a product that would solve a problem with his or her dormitory room. We asked students to examine their rooms looking for "design flaws" or problems they had using their room efficiently and effectively. Students designed small furniture items or study aids, for the most part, to address the lack of space and efficiency in their rooms.

When submitting their designs for review, each student had to submit a final paper responding to the following questions:

a) Assess the sustainability of your design in all four contexts (environmental, social, technical, and economic).

b) What is the "weak link" in your design (What will break or wear out first?)? How easy will it be to fix it when it fails?

c) How could your design be improved in any or all of the contexts? (or...How would you design and build it better next time...if you had no material, financial, or time constraints?)

d) Describe the cognitive processes you used to conceive, design, and build your design. Include how you did the thinking to come up with the design, how you developed the final design, and how you built it.

Most students completed this project successfully and demonstrated a fundamental understanding of cognitive processes, the design process, and of sustainability. Our assessment validated these facts. The formal six-course three-year design sequence builds upon these skills, as well as on the other projects described here.

\section{Feedback and Assessment}

We have a significant interest in learning how our students respond to the tool-based design and build assignments that utilize cognitive process skills. We hope to be providing instruction that is at an appropriate level in order to prepare students with minimal experience without boring those who have prior experience. The assessment of student attitudes toward the instruction, as well as their own skills, is a way for us to determine how we might improve our delivery. Furthermore, we hope to continue to assess the level to which students are applying the cognitive processes discussed in the classroom to their projects. 
We also assessed student learning of tool usage fundamentals through embedded questions on exams.

\section{A) Boot Camp Experience}

To help us evaluate the boot camp sessions, we asked students if boot camp increased their confidence in hand tool usage. In response, $55 \%$ of students agreed that the boot camp session increased their confidence with hand tools with $40 \%$ strongly agreeing with this statement. We were uncertain of what the benefit boot camp would be since we teach tool use at a basic level. It is interesting to observe that $40 \%$ of students indicated strong agreement that boot camp increased their confidence in hand tool usage.

\section{B) Widget Assembly}

Each assembly was assessed for completeness, proper fitment of screws, use of proper tool bits to create counterbores and countersinks, and completeness of threads. The grading scale is set up so that students who hand something in score a significant number of points regardless of quality. This reflects our primary goal of having students interact with the tools rather than achieve any level of mastery in the first exercise. Out of 76 students, 74 turned in an assembly, scores for completed assignments ranged from $88 \%-100 \%$, and the average score was $96 \%$.

\section{C) Lathe Part}

The lathe assignment was assessed for inclusion of the required features and inclusion of optional features. Inclusion of all required features was worth $75 / 100$ points; additional points were awarded based on instructor perception of the difficulty, creativity, and utility of optional features. Note that all students added optional features. Out of 76 students, 73 turned in a lathe part; scores for completed assignments ranged from $80 \%-100 \%$, and the average score was $96 \%$.

\section{D) Go-NoGo Gauge}

The assessment of student performance on the gauge project was divided evenly among the required documentation (Parts 1-5), and part construction (Part 6). Generally speaking, higher grades are given to students who:

- $\quad$ Provide multiple design concepts

- $\quad$ Provide adequate description of their design concepts

- Recommend tolerances for their gauge that will not allow "bad" parts to pass

- $\quad$ Differentiate between failure modes of rejected parts

- $\quad$ Provide an adequately dimensioned and toleranced drawing of their proposed gauge

- Build a gauge that meets their specifications and prove it through inspection

Student ability to accurately build and inspect their gauge was graded on a sliding scale based on their stated tolerance (build) and twice the resolution of their inspection tool (dial caliper: $\pm 0.002 ")$. Each gauge includes two "critical" build dimensions so that students had two 
opportunities to machine a critical dimension within specified tolerances and to verify it was correct via inspection. Table 1 summarizes student performance in these areas.

Table 1: Student performance in the Build and Inspect portions of the Go-NoGo gauge

\begin{tabular}{|c|c|c|c|}
\hline \multicolumn{2}{|l|}{ Build } & \multicolumn{2}{|c|}{ Inspect } \\
\hline error & $\begin{array}{c}\% \text { of } \\
\text { Builds }\end{array}$ & error & $\begin{array}{c}\% \text { of } \\
\text { Inspections }\end{array}$ \\
\hline 0 (within tolerance) & 60 & $<0.002 "$ & 46 \\
\hline $0.005^{\prime \prime}$ & 18 & $0.005^{\prime \prime}$ & 11 \\
\hline $0.010^{\prime \prime}$ & 5 & $0.010^{\prime \prime}$ & 4 \\
\hline $0.020^{\prime \prime}$ & 4 & $>0.010^{\prime \prime}$ & 39 \\
\hline$>0.020^{\prime \prime}$ & 13 & & \\
\hline
\end{tabular}

The table shows that $60 \%$ of the critical features were machined to specification, and that nearly $80 \%$ were machined to within 0.005 " of the specified tolerance. Although $46 \%$ of the critical features were inspected correctly (within twice the resolution of the inspection tool), the table shows that nearly $40 \%$ were in error by at least 0.010 ". Note that this figure also includes students who did not provide inspection data for their part.

\section{E) Student Attitudes toward Construction Projects}

Students were given a course survey at the end of the semester that revealed student attitudes toward the tools training and practice received in Engineering 112. When asked which part of the course they liked the best, 26 out of 72 student responses included references to the assembly assignment, build projects, working in the shop, or working with machines. Three students specifically referenced the lathe in their response. This suggests that many students have developed a positive attitude toward working with machines such as those required for these assignments. Further support for this assertion is that $99 \%$ of students indicated some level of agreement with the statement "The design project and tools training was a valuable learning experience," with $68 \%$ of students indicating strong agreement. On the negative side, three students indicated that their greatest dislike was that there were too few tools relative to the number of students. In other open ended responses, one student indicated that learning the tools was hard.

\section{F) Semester Design Project Assessment and Discussion}

At the conclusion of the semester, we conducted a simple survey of the 72 students in our three Engineering 112 classes. Our purpose was to determine students' attitudes towards design and build projects (especially the Semester Design Project), the cognitive skills they learned in class and employed during the projects (reflection, visualization, structured problem solving), and their comfort level working with hand tools (they were required to use only non-power hand tools to construct their designs). This assessment serves as a "base line" for further assessments during the design sequence. 
Students were given the surveys in class, were not required to identify themselves on the survey, nor were the instructors in room during the survey administration. Despite the well-known limitations of self-report surveys, results were informative and promising (See Table 2). It is clear that our approach to teaching design using a cognitive skills as well as a "design and build" approach had value to our students.

Surveys were scored on a 1-6 basis as follows:

$$
\begin{array}{ll}
6=\text { Strongly Agree } & 3=\text { Slightly Disagree } \\
5=\text { Moderately Agree } & \text { 2=Moderately Disagree } \\
\text { 4=Slightly Agree } & \text { 1=Strongly Disagree }
\end{array}
$$

Table 2: Design Project Survey Responses

\begin{tabular}{|l|l|l|l|l|l|}
\hline \multicolumn{6}{|l|}{ I find working and thinking in groups on design projects valuable. } \\
\hline $\begin{array}{l}\text { Strongly } \\
\text { Agree }\end{array}$ & $\begin{array}{l}\text { Moderately } \\
\text { Agree }\end{array}$ & $\begin{array}{l}\text { Slightly } \\
\text { Agree }\end{array}$ & $\begin{array}{l}\text { Slightly } \\
\text { Disagree }\end{array}$ & $\begin{array}{l}\text { Moderately } \\
\text { Disagree }\end{array}$ & $\begin{array}{l}\text { Strongly } \\
\text { Disagree }\end{array}$ \\
\hline $53 \%$ & $36 \%$ & $11 \%$ & $0 \%$ & $0 \%$ & $0 \%$ \\
\hline
\end{tabular}

2) I found reflecting on a design assignment (before starting the design) a valuable thinking tool.

\begin{tabular}{|l|l|l|l|l|l|}
\hline $\begin{array}{l}\text { Strongly } \\
\text { Agree }\end{array}$ & $\begin{array}{l}\text { Moderately } \\
\text { Agree }\end{array}$ & $\begin{array}{l}\text { Slightly } \\
\text { Agree }\end{array}$ & $\begin{array}{l}\text { Slightly } \\
\text { Disagree }\end{array}$ & $\begin{array}{l}\text { Moderately } \\
\text { Disagree }\end{array}$ & $\begin{array}{l}\text { Strongly } \\
\text { Disagree }\end{array}$ \\
\hline $46 \%$ & $43 \%$ & $11 \%$ & $0 \%$ & $0 \%$ & $0 \%$ \\
\hline
\end{tabular}

\begin{tabular}{|l|l|l|l|l|l|}
\hline 3) In general, I find using a structured problem solving process valuable. \\
\hline $\begin{array}{l}\text { Strongly } \\
\text { Agree }\end{array}$ & $\begin{array}{l}\text { Moderately } \\
\text { Agree }\end{array}$ & $\begin{array}{l}\text { Slightly } \\
\text { Agree }\end{array}$ & $\begin{array}{l}\text { Slightly } \\
\text { Disagree }\end{array}$ & $\begin{array}{l}\text { Moderately } \\
\text { Disagree }\end{array}$ & $\begin{array}{l}\text { Strongly } \\
\text { Disagree }\end{array}$ \\
\hline $22 \%$ & $56 \%$ & $22 . \%$ & $0 \%$ & $0 \%$ & $0 \%$ \\
\hline
\end{tabular}

\begin{tabular}{|l|l|l|l|l|l|}
\hline \multicolumn{6}{|l|}{ I found visualizing a design a valuable design tool. } \\
\hline $\begin{array}{l}\text { Strongly } \\
\text { Agree }\end{array}$ & $\begin{array}{l}\text { Moderately } \\
\text { Agree }\end{array}$ & $\begin{array}{l}\text { Slightly } \\
\text { Agree }\end{array}$ & $\begin{array}{l}\text { Slightly } \\
\text { Disagree }\end{array}$ & $\begin{array}{l}\text { Moderately } \\
\text { Disagree }\end{array}$ & $\begin{array}{l}\text { Strongly } \\
\text { Disagree }\end{array}$ \\
\hline $61 \%$ & $32 \%$ & $7 \%$ & $0 \%$ & $0 \%$ & $0 \%$ \\
\hline
\end{tabular}

5) I found using a variety of thinking methods a helpful design tool.

\begin{tabular}{|l|l|l|l|l|l|}
\hline $\begin{array}{l}\text { Strongly } \\
\text { Agree }\end{array}$ & $\begin{array}{l}\text { Moderately } \\
\text { Agree }\end{array}$ & $\begin{array}{l}\text { Slightly } \\
\text { Agree }\end{array}$ & $\begin{array}{l}\text { Slightly } \\
\text { Disagree }\end{array}$ & $\begin{array}{l}\text { Moderately } \\
\text { Disagree }\end{array}$ & $\begin{array}{l}\text { Strongly } \\
\text { Disagree }\end{array}$ \\
\hline $38 \%$ & $39 \%$ & $19 \%$ & $4 \%$ & $0 \%$ & $0 \%$ \\
\hline
\end{tabular}

6) I find that balancing my relationship with technology is a valuable academic strategy.

\begin{tabular}{|l|l|l|l|l|l|}
\hline $\begin{array}{l}\text { Strongly } \\
\text { Agree }\end{array}$ & $\begin{array}{l}\text { Moderately } \\
\text { Agree }\end{array}$ & $\begin{array}{l}\text { Slightly } \\
\text { Agree }\end{array}$ & $\begin{array}{l}\text { Slightly } \\
\text { Disagree }\end{array}$ & $\begin{array}{l}\text { Moderately } \\
\text { Disagree }\end{array}$ & $\begin{array}{l}\text { Strongly } \\
\text { Disagree }\end{array}$ \\
\hline $40 \%$ & $35.5 \%$ & $18.5 \%$ & $1.5 \%$ & $3 \%$ & $1.5 \%$ \\
\hline
\end{tabular}




\begin{tabular}{|l|l|l|l|l|l|}
\hline 7) I am confident in the use of machine tools and hand tools available in the studio. \\
\hline $\begin{array}{l}\text { Strongly } \\
\text { Agree }\end{array}$ & $\begin{array}{l}\text { Moderately } \\
\text { Agree }\end{array}$ & $\begin{array}{l}\text { Slightly } \\
\text { Agree }\end{array}$ & $\begin{array}{l}\text { Slightly } \\
\text { Disagree }\end{array}$ & $\begin{array}{l}\text { Moderately } \\
\text { Disagree }\end{array}$ & $\begin{array}{l}\text { Strongly } \\
\text { Disagree }\end{array}$ \\
\hline $34 \%$ & $27.5 \%$ & $27 \%$ & $7 \%$ & $4 \%$ & $.5 \%$ \\
\hline
\end{tabular}

\begin{tabular}{|l|l|l|l|l|l|}
\hline 8) I believe building an object I have designed will improve my design skills. \\
\hline $\begin{array}{l}\text { Strongly } \\
\text { Agree }\end{array}$ & $\begin{array}{l}\text { Moderately } \\
\text { Agree }\end{array}$ & $\begin{array}{l}\text { Slightly } \\
\text { Agree }\end{array}$ & $\begin{array}{l}\text { Slightly } \\
\text { Disagree }\end{array}$ & $\begin{array}{l}\text { Moderately } \\
\text { Disagree }\end{array}$ & $\begin{array}{l}\text { Strongly } \\
\text { Disagree }\end{array}$ \\
\hline $62.5 \%$ & $25 \%$ & $11 \%$ & $1.5 \%$ & $0 \%$ & $0 \%$ \\
\hline
\end{tabular}

9) I have previous experience with the types of hand tools and machine tools that are in the studio.

\begin{tabular}{|l|l|l|l|l|l|}
\hline $\begin{array}{l}\text { Strongly } \\
\text { Agree }\end{array}$ & $\begin{array}{l}\text { Moderately } \\
\text { Agree }\end{array}$ & $\begin{array}{l}\text { Slightly } \\
\text { Agree }\end{array}$ & $\begin{array}{l}\text { Slightly } \\
\text { Disagree }\end{array}$ & $\begin{array}{l}\text { Moderately } \\
\text { Disagree }\end{array}$ & $\begin{array}{l}\text { Strongly } \\
\text { Disagree }\end{array}$ \\
\hline $35 \%$ & $30.5 \%$ & $16.5 \%$ & $2.5 \%$ & $8.5 \%$ & $7 \%$ \\
\hline
\end{tabular}

The generally strong responses to Questions 1-6 are not surprising. Early in the course, students were exposed to a variety of cognitive process assignments that demonstrated the effective use of these methodologies in a variety of contexts.

For example, students successfully used reflection as a tool for developing ideas at a variety of times during the design process. Developing visualization skills helped students while sketching and drawing designs as well as developing CAD drawings. The structured problem solving skills students learned provided them with a linear approach to understanding and applying the design process. More importantly, students recognized the value of using a variety of cognitive skills when solving a design problem or generating an idea. Question 6 asked students about the class exercises they completed in an effort to balance the amount of time they spent using social networks, video games, texting, or surfing the net. All but four of the 71 students responding believed that restricting the amount on time they spent with technology helped improve their thinking skills.

Our developmental approach to teaching cognitive skills allows students to employ these methods successfully in increasingly sophisticated scenarios-first in personal contexts, later in informal case studies, and finally in brief in-class design project assignments. By the time they were working on their semester design project, most all students had a reasonable level of confidence in their newly acquired thinking skills.

Student responses to Question 7 ("I am confident in the use of machine tools and hand tools available in the design studio.") can be compared to the objective results shown in Table 1 in which student performance related to the construction of the Go-NoGo gauge project is tabulated. The table shows that $60 \%$ of the students constructed their device so that the final dimensions were in tolerance; this correlates closely with the number of students who reported either strong or moderate agreement with Question 7. On the other end of the scale, Table 1 also shows that $13 \%$ of the students were more than 0.020 " outside of tolerance on their Go-NoGo 
gauge; this correlates well with the $14 \%$ of students who reported any level of disagreement with Question 7. Although we don't know if the individuals who were confident are the same individuals who performed well, the overall trend suggests that student confidence levels are reasonably appropriate.

The negative responses to Question 7 (tool use confidence) and Question 9 (tool use prior experience) are of concern. Considering the importance of tool use skills in a design and build program, we conducted further research into tool use and cognitive processes. ${ }^{22}$ Since tool use skills are critically important for each of our students to learn, we have increased tool use instruction in the first two classes of the formal design sequence (sophomore year). As well, we have discussed students' tool use skills in the Engineering 112 class and during design class the following semester in order to identify students who need additional instruction or further explanation of how tool use and developing an effective design process are mutually dependent.

\section{Conclusion}

We are moving forward in our efforts to develop a design program that utilizes design and build strategies as well as cognitive processes to teach design. As the design sequence rolls out, we are teaching ethics and values, aesthetics, engineering communications and sustainability in four contexts (environmental, social / cultural, economic, and technical).

Since the James Madison University School of Engineering is new (we have sophomores this year), our desire to experiment with innovative approaches to teaching engineering leads us to experimentation in a variety of research and instructional areas. Our work is being well supported by the National Science Foundation, the University, and industry. While we do not eschew traditional approaches to studying engineering, we feel there is significant call to graduate engineers skilled and imaginative enough to face the problems we face in our communities, our businesses, and as a global society.

\section{Bibliography}

1. Zydney, J. "Cognitive Tools for Scaffolding Students Defining an Ill-structured Problem.” Journal of Educational Computing Research, Vol. 38(4) 353-385. 2008.

2. Newstetter, W. and J. Kolodner. "Learning to Change the World: A Case Study of a Mechanical Engineering Design Course.” EduTech Institute, Georgia Institute of Technology. 1995.

3. Keller, C. and J. Keller. Cognition and Tool Use: The Blacksmith at Work. New York: Cambridge University Press. 1996.

4. Malicky, D., Kohl, J., and Huang, M. "Integrating a Machine Shop Class into the Mechanical Engineering Curriculum: Experiential and Inductive Learning." ASEE National Conference, 2007.

5. Bailey, D. and S. Barley. "Return to Work: Toward Post-industrial Engineering." IIE Transactions 37, 737752. 2004.

6. Brown, S., Collins, A., and P. Duguid. "Situated Cognition and the Culture of Learning." Educational Researcher, 32-42, January-February, 1989.

7. Salomon, G., Perkins, D., and T. Globerson. "Partners in Cognition: Extending Human Intelligence with Intelligent Technologies." Educational Researcher, 2-9, April 1991. 
8. Vygotsky, L.S. The Collected Works of L.S. Vygotsky: Vol. I, Problems of General Psychology. New York: Plenum. 1987.

9. $\quad$ Piaget, J. Structuralism. New York: Basic Books. 1970.

10. Dewey, J. Experience and Education. New York: Macmillan. 1938.

11. Cole, M. and J. Wertsch. "Beyond the Individual-social Antimony in Discussion of Piaget and Vygotsky." Human Development 39, 250-256, 1996.

12. Pea, R. in Distributed Cognitions: Psychological and Educational Considerations. (Gabriel Salomon, editor). New York: Cambridge University Press. 1993.

13. Pea, R. "Beyond Amplification: Using Computers to Reorganize Human Mental Functioning." Educational Psychologist, 20, 167-183. 1985.

14. Maravita, A. and Iriki, A. "Tools for the Body (schema)" TRENDS in Cognitive Sciences, Vol.8 No.2. February 2004.

15. Maravita, A. and A. Iriki. "Tools for the Body (schema)." TRENDS in Cognitive Sciences, Vol.8 No.2. February 2004.

16. Wilson, Frank R. The Hand. New York: Pantheon Books, 1998.

17. Wilson, Frank R. The Hand. New York: Pantheon Books, 1998. p. 275.

18. Hall, D., Cronk, S., Brackin, P., Barker, M., Crittenden, K. Living with the Lab: A Curriculum to Prepare Freshman Students to meet the Criteria of "The Engineer of 2020." ASEE Annual Conference and Exposition, June 22-25, 2008, Pittsburgh, Pennsylvania.

19-22. Pappas, E. and R. Prins. Design and Build: Teaching Cognitive Skills through Tool Use. ASEE South East Sectional Conference, Blacksburg, Virginia. April, 2010. 